\title{
ECONOMIC HAZARDS IN THE FAIR LABOR STANDARDS ACT
}

\author{
Norl SARgENT*
}

The Fair Labor Standards Act has been in operation too short a time to permit valid conclusions, based upon evidence, as to its actual economic effects. To say, on the one hand, that all wage increases since the Act went into operation, or, on the other, that all lay-offs since then, are due to the Act would be a naive, and statistically insupportable, inference. It is possible, however, to make some prognostications as to what long-run effects the Act may have if it continues on the statute books, and is enforced.

I. As it stands, the Act will not affect the majority of so-called "sweatshop" conditions.

The Act excludes purely intrastate industries, thus further actually providing protection to sweatshops. The Act does permit some intrastate industries under certain circumstances to be subject to federal wage and hour control, but even this limited exception apparently does not apply to the service industries, trades, and occupations, in which lie, probably, the bulk of sweatshop labor. We must believe, therefore, either that the Act is not really intended to eliminate sweatshops or that it seeks to do so in an utterly inadequate manner. Sweatshop conditions are essentially local conditions; they vary widely from industry to industry and community to community, even within the same state. It is a problem especially difficult for federal legislation to cope with in any intelligent and effective manner.

But let us suppose that the Federal Government can reach down to the "sweatshop" level of wages. At this point-and even above it-there are marginal workers whose productive value is very limited. A minimum wage will inevitably make it impossible for some marginal laborers to find work. The higher the minimum wage is put, the greater will be the volume of government-forced unemployment; and the larger the number of persons on relief.

From a social standpoint there are a number of marginal workers in the country who actually cannot earn a certain wage. There are a certain number of marginal industries which for one reason or another cannot pay a wage which we all might believe to be a desirable wage. Society must choose whether it wishes to have those marginal industries and marginal workers continued on a basis of what might be

* Secretary, National Assaciation of Manufacturers. 
termed marginal wages, or whether it wishes to eliminate them from industry and have their production taken off the market, and support the workers on relief or by other means. To measure how great the problem may become we note that Dr. Paul Douglas states that: "If wages are pushed up above the point of marginal productivity, the decrease in employment would normally be from three to four times as great as the increase in hourly rates, so that the total income of the working class would be reduced."

\section{The Act is based on the unsound "purchasing power" theory.}

Evidence submitted in behalf of the Act when it was under consideration in Congress indicated a belief that it would result in higher average wages, regardless of other economic forces which might be operating. Indeed, one of the apparent backgrounds of the wage-control proposal is the so-called purchasing power argument, widely advocated by many persons ever since 1929 . This theory assumes that if we can only increase the money people have to buy goods with, we can assure prosperity. This was the basis of the effort in December 1929 to persuade employers to keep up wage rates at all costs. They did so with the result that millions of men became unemployed because the goods they could produce could not be sold for enough to enable anyone to hire them at the former wages. This "purchasing power" theory was also the basis of the N.R.A. In its penetrating analysis of the N.R.A., the Brookings Institution reports:

"The main outlines of the purchasing power theory are fairly simple. Employers were to raise wages and thus expand their pay rolls. The return flow of these enlarged payments in the form of demand for the products of industry would increase the physical volume of goods and services sold. . . Employers must not raise their selling prices as fast or as far as they raised wage rates. . . . In practice it did not work out as planned. ... The anticipated lag of price advances behind wage increases did not in general occur. . . . On the average, prices rose ahead of wage rates."2

The federal wage and hour control measure seems to be predicated upon the same economic error; it is in substance a new N.R.A. from the standpoint of its economic basis, even if the method used differs.

The purchasing power theory of wages is a phase of the so-called underconsumption theory as to the cause of the business crisis-an inability to sell part of the goods produced at a price equal to or exceeding their cost. It is sufficient to say at this point that the theory is condemned by leading economists. Thus, Dr. Wilhelm Röpke, of Istanbul University, perhaps the world's principal authority on business cycles, concludes:

"If we pump purchasing power into the hands of the masses without treading the path to inflation, there must occur a diminution in the incomes of entrepreneurs, so it is only the composition of demand and not its total amount that is changed. . . The question arises here also whether the composition of demand as determined by the distribution of income and its changes is not an important factor for the explanation of

1 TheORY OF WAges (1934) $50 \mathrm{r}$.

a The National Recovery Administration (1935) 757-760. 
disturbances of economic equilibrium. . . . Let us take ... the idea that the share of the workers' income in the total national income is too small ... to secure equilibrium in the economic system. Then the objection immediately presents itself that the crisis is preceded not by a slack time but by a boom in which the income of the worker rises along with the total income. In the same vein it must be objected that, contrary to what the underconsumption theory would lead us to expect, it is the consumers' goods industries which are usually the least and the last affected by the depression. ... This is really fatal to the idea that it is the appearance of a deficiency of consumers' purchasing power which is the factor bringing the boom to an end."3

And Dr. Gustav Cassel of Stockholm University, in the present author's opinion one of the world's leading economists, declares in his On Quantitative Thinking in Economics (I935):

"Certain charlatan teachings that have recently taken a conspicuous place in popular discussion of social economy as well as in political agitation ... particularly in the United States, lay much stress on a supposed insufficiency of income for buying the whole product of the community. ... This conclusion is wrong. It has simply overlooked that the cost of production of new capital goods for replacement represents an income for those engaged in this reproduction. This income-which is at disposal for buying the net product-is equal to the total value of the replacement goods, and thus also to the total sum written off for depreciation and debited to the cost of the net product. Thus total income suffices for buying total net product." 4

III. Wage and hour control legislation cannot be fully effective unless accompanied by economic planning in other directions.

Even if we could accept the "purchasing power" theory as sound, there are still many grave difficulties involved in proposals to establish federal wage control. For example, there are only three directions in which a wage rate can be fixed, namely:

(I) At the free-market price. If it is fixed here, then obviously it is a waste of time to have any board or legislation at all.

(2) Below the free-market price. If it is fixed here then the demand for labor and its supply get out of adjustment. The demand for labor will be increased and its supply lowered. The eventual answer would have to be the rationing of consumers, in order to limit the demands for goods and thus reduce the demand for labor-thus limiting the freedom of consumers.

(3) Above the free-market price. If the wage rate is fixed here then once again we will find the demand for labor and its supply getting out of adjustment. The demand for labor will be reduced and its supply increased. To meet this situation the government would have to compel an increase in production, regardless of the demand for goods at the price involved.

Perhaps these extremes would not result. But it is certain that government cannot control wages without soon being faced with the necessity of controlling prices, either directly, or by seeking to control such other cost factors as taxes, insurance, interest rates, and so forth. Gardiner Means, one of the Government's economic advisers, writes:

\footnotetext{
${ }^{3}$ Crises and CrCles (1936) 86-90. $\$ 66,67$.
} 
"Partial planning may easily lead to uneconomic use of resources and a distortion of economic relationships. .... Industrial policy-making for each industry could, obviously, have very disturbing results if the relations among industries were not part of the picture."ש

Dr. Alvin H. Hansen, formerly economic adviser to the State Department, was a member of the Columbia University Committee on Economic Reconstruction which in r934 pointed out that the true economic goal should be "planned flexibility" and that this could only be accomplished by governmental "orderly adjustment" or continuous control of such "fundamental cost groups" as (I) interest charges, (2) depreciation, (3) railroad and public-utility rates, (4) basic fuel and metal-products prices, (5) taxes, (6) wage rates. ${ }^{6}$

In other words, this Act can only be fully effective, if at all, with complete economic planning of other economic factors as well. It is impossible to inject an act of Congress into an economic machine and stop one major part of it-the free movement of prices-and expect the rest to go on as before. Once government starts to interfere in direct economic control, it is difficult to stop doing so.

IV. It will be administratively difficult or impossible to administer an Act which includes so many factors in the determination of wages.

In addition to the general problem of the economic point at which to fix wages there are other practical difficulties. Consider, for instance, the problem of differentials. The Act provides that eleven factors may be considered in fixing wage rates:

(I) "Reasonable cost" of board, lodging and other facilities furnished employees.

(2) "Conditions in the industry."

(3) Economic condition of an industry.

(4) Competitive condition of an industry.

(5) Wage which would "substantially" curtail employment in an industry.

(6) Transportation costs.

(7) Living costs.

(8) Production costs.

(9) "Wages established for work of like or comparable character by collective labor agreements."

(ro) "Wages paid for work of like or comparable character by employers who voluntarily maintain certain minimum wage standards."

(II) Impaired earning capacity of employees.

The magnitude of the problem involved is further realized when we find that the United States Census of Occupations reports gainful workers in over 625 classifications; the United States Employment Service now uses approximately 6,300 separate occupational classifications.

Here is the dilemma-if we do not provide differentials we are nonrealists, refusing to recognize the fact that differentials have developed and exist, and that ignoring them would almost completely alter and perhaps even wreck the complicated and delicate economic machine.

-Ware and Means, The Modern Economy in Action (i936) Ig9.

- Report, pp. 50, 217. " 5 . 
If we recognize 600 or 6,000 separate occupational classifications and attempt to fix wage rates for them under the eleven differential standards in this Act, there will be an administratively difficult task, one probably incapable of being carried out, with the result that administration will break down and the whole measure be repudiated in practice if not in legislation-but with great economic harm occurring in the meantime. This is a perfectly huge task-an enormously complicated economic planning responsibility-to impose at any time, and particularly so when business is still subject to relatively new burdens imposed by the Social Security Act and the National Labor Relations Act.

$V$. There will be a tendency under the Act to decrease the spread between skilled and unskilled wages.

Will a legal minimum wage tend to become the maximum wage? I think there is no doubt that such a tendency will exist, although only in a relatively few cases will the minimum and maximum actually be identical. What will happen is that the percentage spread between the minimum and maximum will become less. The attempt by legislation, as proposed in Section 18 of this Act, to prevent this development by administrative fiat, is as economically ridiculous as the statement made to King Canute by his courtiers that the tide would recede at his mere command. Certainly it has been the experience in foreign nations where minimum-wage legislation has existed that over a period of years there is an increasing tendency for the percentage spread between minimum and maximum wages to decrease.

It is the author's opinion that there has been for many years a tendency for the percentage differential between the wages of skilled and unskilled workers to decrease. A federal wage and hour act will simply speed up this natural economic tendency. Not only is this true, but it is further promoted by the constant tendency where minimum-wage legislation exists "to merge into a tendency towards the general regulation of wages.?

VI. Rigidities in our economic system will be increased by the Act.

If the Federal Wage-Hour Act becomes fully operative it will establish additional rigidities in our economic system which would make the next depression worse than it otherwise need be. These rigidities would be first in the field of wages and second in the field of prices.

We need less rigidity or stability, instead of more. We need more flexibility. It is a mistake to adopt measures which tend to "freeze" either wages or prices into our economic system. The result of such rigidities is to make economic adjustments more difficult and a depression more likely or more severe when prompt economic adjustments would be economically desirable.

In this connection attention is directed to these observations by Dr. Wilhelm Röpke:

"The success of direct interferences with the structure of production, costs, and prices, aimed at the mitigation of the trade cycle is extremely dubious. . . . The most severe

'Douglas, Wage Theory and Wage Policy (1939) 39 INT. LAB. REv. 322; see also Reddaway, Australian Wage Policy (1938) 37 id. 315. 
of all depressions has descended upon us just in a moment when capitalism has been disfigured by an excess of interferences of all kinds (. . . wage regulations . . . restrictions on the movement of capital, etc.) until it is practically unrecognizable. . . . It is ... palpable that we should speak not of a 'crisis of capitalism' but a 'crisis of interventionism." "8

Indeed, from the standpoint of basic economics, easily the worst effect of this Act might be the establishment of wage and price rigidities which would intensify the severity of our next business recession. Secretary Wallace and Mr. Gardiner Means have especially stressed during the past few years the necessity of price flexibility, with which wage flexibility is intricately connected.

Dr. Willford I. King, former president of the American Statistical Association, soundly observes that:

". . . the higher prices made necessary by the advances in wage rates will inevitably tend to lessen the volume of sales of their products. The extent to which sales will shrink in the case of any particular product will depend upon the elasticity of the demand for that particular product. The demand for bread is relatively inelastic, hence the falling off in sales resulting from a $5^{\circ}$ per cent increase in the price of bread is likely to be relatively slight. On the other hand, a $5^{\circ}$ per cent rise in the price of beefsteak will cause a marked shrinkage in the volume which can be marketed. In practically all products, however, a rise in price is accompanied by some decline in sales volume (italics added).

"As sales volume shrinks, the need for workers to replace these products obviously lessens, and workers are laid off. A fundamental lesson which workers in general have yet to learn is that they, as well as their employers, have a vital interest in keeping down wage costs per unit of output. This is true both from their positions as employees and their position as consumers. Consumers include, of course, employers, employees, independent workers, and the dependents of these classes. The idea that, in some way, high wage costs can be passed on to some mythical body of consumers outside the classes mentioned is, of course, based upon the most careless kind of reasoning. Higher wage costs react adversely therefore, upon both employers and employees, not only in their capacity as producers, but also in their capacity as consumers.

". . . Unduly high wage costs per piece are burdensome to the consumers of the products, and hence these consumers are unable to purchase as large a volume of the goods produced by the labor in question as they could buy if wage costs per unit were lower." 9

In our analysis of the economic aspects of the wage-control provisions of the Fair Labor Standards Act, we can well ponder the following opinions expressed a few years ago by one of the country's citizens most prominently in the limelight today:10

"Private control of a monopolistic nature which could limit production according to any plan or formula being impossible, it may be worth while to consider in passing the possibility of Government control of this industry.

"It is difficult to conceive how any such control through political agencies could function without putting strait-jackets upon the supply of industrial energy that would bring paralysis of initiative and enterprise in all other business lines. The quantity . . needed for the factories and homes of America cannot be determined in advance, simply is not subject to exact forecast because it varies from day to day with the ebb and flow of business, not only in America but around the world. The writer is convinced that such an

${ }^{8}$ Op. cit. supra note 3 , at $159-160$.

- Wage Rates in the General Welfare (1939) 29 AM. Econ. Rev. 34, 39, 47.

${ }^{10}$ The Miners Fight for Adrerican Standards, 2 i-22. 
indeterminate quantity cannot be regulated artificially in a manner even to promote stability, much less insure it. ... .

"The only manner in which we can hope to have the . . . industry function in tune with the rest of the industrial system, is to see that ... (it) remains at all times subject to the same economic laws which are simultaneously determining the volume of all production and distribution of commodities."

These statements were written by John L. Lewis, president of the United Mine Workers, in 1925 .

VII. Dividing the volume of work will not increase production and living standards.

The theory of the Fair Labor Standards Act seems to be that employee welfare can be increased by compulsory sharing of existing work, and that this will be promoted by heavy penalties on overtime employment. Let us assume that the Act is fully operative in all industries, and that average hours of work are reduced, but the same weekly pay maintained (for that seems to be the formula). One of two results might follow-(r) additional workers would be employed, but since the unit cost of production would be higher the consumers would pay more; or, (2) since the consumer would pay more he would buy less, demand would fall off and so would employment. Here again we find the Brookings Institution has thus summarized the principles involved:

"The much advocated 30 -hour week with 40 -hours pay would produce an increase in prices and the cost of living calculated to widen much further the disparity between the income of the country and the prices of the things it buys...."11

If the employers do not raise prices to offset the higher cost, they will be ruined and go out of business and employment will be decreased; but if they do raise prices, there will be no extra purchasing power to buy the products, the total demand will be decreased, and once again employment will suffer. No one can whisk away the inseparable connection between costs, output, and prices. To increase costs before there is increased demand is to put the cart before the horse, and run the risk of making matters worse instead of better.

Increased living standards for the country as a whole can result only from an increased volume of work; they will not be increased by simply dividing up the existing volume of work. We need national policies which will increase the total volume of work done instead of trying to maintain the volume of work at existing shrunken levels. The Brookings Institution has soundly pointed out that:

"The universal 30 -hour limitation advocated in some quarters, with a practically attainable average of 27 or 28 hours, would be clearly a freezing of partial unemployment with a low standard of living." 12

The Chairman of the Federal Reserve Board, M. S. Eccles, gave this sound caution in a public statement on March $15,1937::^{13}$

2I Op. cit. supra note 2 , at 843 .

${ }^{23}$ Id. at 838 .

${ }^{13}$ N. Y. Times, March 16, 1937, p. 9, col. x. 
"Increased wages and shorter hours when they limit or actually reduce production are not at this time in the interest of the public in general or in the real interest of the workers themselves."

Certainly, we cannot assist in the elimination of poverty by reducing the supply of goods to be consumed.

Prof. J. M. Clark, of Columbia University, former president of the American Economic Association, says that:

"A compulsory increase of wages, by increasing costs of production, might lead to restriction of output in the attempt to protect profits-in short, to just the opposite of the desired effect." 14

Dr. Thomas N. Carver, of Harvard University, another former president of the American Economic Association, summarizes his observations as follows: ${ }^{15}$

"The hope often expressed, that shortening the working time of both labor and capital, with no diminution of wages or interest, would relieve unemployment, is a vain hope, based upon insufficient analysis."

Yet another effect of hour-control legislation must be considered-that the supply of labor available for production of war supplies would be so restricted if a war should come, that the hour provisions of the present Act would presumably have to be either repealed or suspended.

VIII. Competition with foreign producers either at home or abroad will be made more difficult by the Act.

How will this Act, when fully operative, affect our national volume of trade? There are two principal groups of manufacturers and employees directly interested. First, those manufacturers and employees engaged in making goods which are exported in considerable quantity. If their production costs and resulting selling costs are raised, then the exports of competitive products will decrease. Second, those manufacturers and employees engaged in making goods which either actually or potentially are in competition in American markets with goods from abroad. If American production and selling costs are increased then the difficulty of selling in competition with imports of foreign-made goods will be increased. The result would be decreased production and employment in many American industries.

IX. Such legislation favors larger business enterprises.

This Act will in the final analysis tend to favor so-called "big business" as compared to "little business." No general rule can be laid down-many small plants pay top wages in their industries-but generally speaking the big company tends to pay higher wages than its small competitors. The result is that, if costs are raised by wage and hour control, the larger company will, as a rule, have its costs increased least; the smaller company will be given an additional competing handicap.

In actual practice the Act will inevitably result in greater proportional cost increases to companies with lower average wages than to those with higher average

14 Report, Committee on Economic Reconstruction, Columbia Univ. 1934, p. 125.

${ }^{15}$ The Theory of the Shortened Working Week (1936) 26 AM. Econ. REv. 45x, 462. 
wages, and this will favor the bigger companies in general. Under the N. R. A., for example, the Government could have rejected code provisions-wages, hours, or any others-which gave advantages to the larger companies; but that was not the actual experience. Who does not recall the report of the so-called Darrow Commission, appointed by President Roosevelt, which reported that the N. R. A. definitely and substantially favored "big business" and handicapped "little business"?

\section{$X$. The Act will tend to establish new geographical relationships.}

The Act now states that "no minimum wage rate shall be fixed solely on a regional basis"-but does provide that comparative transportation, living, and production costs shall be taken into account. But after I945 there will be a flat nation-wide minimum wage. It seems inevitable that this will have some effect in lessening competitive advantages of some sections of the country as compared with others, and will possibly reverse, or at least eliminate, trends in the location of industry in the past forty years.

While perhaps not as fundamentally important as the foregoing listing of some of the long-run effects of federal wage-hour legislation, yet there are some economic effects which are worth noting.

(I) The Act has resulted in forcing payment of overtime to clerical and office workers who customarily work relatively short hours, and have steady employment, but occasionally must work longer hours, as in getting out reports and audits. Many covered employees should, as a matter of fact, be excluded. Thus, the Administrator of the Act says in a letter of March 31, 1939, to Senator Thomas:

"The reasons which dictated the enactment of Federal minimum-wage and maximumhour standards for lower-paid workers are inapplicable to these higher-salaried employees."

(2) The Act has resulted in increased use of time-clocks in industrial offices, a tendency which is both resisted and regretted by many leading personnel experts.

(3) The Act provides exemptions for hour agreements made with certain labor unions, but does not extend the same benefits to similar, or better, agreements made with other groups of employees, or existing under stipulation in a company.

(4) The Act has prevented technical workers from working voluntarily weekends or evenings in order to increase their knowledge and efficiency; practically every large company has many cases of this kind.

(5) Many companies who have paid certain groups of workers on a weekly, or even monthly, basis are being compelled to employ them on an hourly basis; this is resented by the employees.

(6) There is good reason on economic grounds to believe that in determining what constitutes "seasonal employment" the Administrator of the Act has not sufficiently taken into account such factors as the weather handicaps involved (lumbering in New England and the Northwest), or the periods of special availability of supplies (the packing industry). 